\title{
The Influence Evaluation of People's Sugar Cane velopmentolicy Toward Strengthening The Performance of Venture Capital oup In The District of Majalengka And Cirebon In West Java
}

\author{
Dudung Ahmad Suganda \\ Doctoral Candidate Of Administrative SciencesFaculty of Social and Political SciencesUniversity of \\ Padjadjaran Bandung
}

\begin{abstract}
Policy development the people's cane is one of the Government programs in the fields of plantations that aims to satisfy the quantity and quality of sugar cane is needed in all districts / cities in Indonesia. This policy has long been there, starting in 2003 since the beginning of the project the development of sugar cane, but based on the results of the evaluation of the policy conducted each year, the results are still not effective at digging source of financing the strengthening venture capital group for the development of sugar cane people on an ongoing basis. This has been influenced by not fulfillment of the dimensions or the criteria of technical feasibility, economic and financial feasibility, political feasibility, and administration feasibility.

This research aimed to know the magnitude of the influence of evaluation policy the development of sugar cane people on performance strengthening venture capital groups. Through quantitative approach, this research seeked to explain people's sugar cane development policy evaluation in West Java by using the theory of Policy Evaluation Bardach consisting of 4 dimensions, namely: Technical Feasibility, Economic and financial Feasibility, Political Feasibility, and Administrative Feasibility. In addition this research explained the performance gain of venture capital groups. Here researcher used theory of Performance from Abdul Basyid consisting of 5 dimensions: Increasing Venture Capital, increasing production, business development, independence groups, and the growth of the rural Economy institutions. With the method of the survey, the research instruments were then disseminated through questionnaires to 335 people respondents who became a sample; i.e. the evaluators and implementers of policy development of sugar cane To test the hypothesis, the researcher used the analysis of Structural Equation Modeling (SEM).The results showed the magnitude of the influence of evaluation policy the development of sugar cane people on performance strengthening venture capital group in the District of Majalengka and Cirebon determined significantly by technical feasibility, economic and financial feasibility, political feasibility, and feasibility of administrative, with the most dominant dimension i.e. dimensions power administrative support.
\end{abstract}

Keywords: Evaluation Of Policies, The Development Of Sugar Cane People, Strengthening The Performance Of Venture Capital Groups.

\section{INTRODUCTION}

Strengthening Venture Capital Group (PMUK) is one of the efforts to accumulate capital farmer groups sugar cane yield cultivation of sugar cane to restore some of his earnings to the Cooperative Sugar Cane Farmers (KPTR), With PMUK will be obtained capital for the development of sugar cane in the period of the next planting season, Potential funding PMUK in Cirebon and Majalengka from 2003 to 2015 amounted to Rp14.745.060.000, -. But can be rolled out of Rp 4.767.000.000,- or 32.33\%, the remaining Rp 9.978.060.000,or $67.67 \%$ cannot scrolling (Estate Agency of West Java province, 2015). The Government in this Directorate General of Plantation in the guidelines of the Development activities of the Annuals have set policy for developing sugar cane through area expansion (extensification), unloading ratoon (rehabilitation), and intensification (repairing ratoon) as well as other supporting activities such as the preparation of improved seed, strengthening farmer institutions, training Sekolah Lapang Pengendalian Hama Terpadu (SL PHT), and Control Organisme Pengganggu Tumbuhan/Tanaman (OPT) to improve the productivity of sugar cane.

Target dry land sugar cane productivity i.e. $70,000-85000 \mathrm{~kg} /$ hectare for sugar cane sticks and wetland $80000-90000 \mathrm{~kg} /$ hectare of sugar cane sticks (Ministry of Agriculture, 2012). But based on data close to the productivity of sugar cane average reach $54,000 \mathrm{~kg} /$ hectare $(77,14 \%)$. By not achieving the target productivity of sugar cane in West Java means there is a problem associated with the policy, in addition to strengthening the 
performance-related venture capital groups that have been conducted from 2003 to 2015 can only be achieved 32.3\% (Plantation Office Java west, 2015), whereas the strengthening of the working capital is required for the continuity of the implementation of the development of sugar cane in the period of the next planting season. Development of sugar cane as one of the Government's policy aims to improve the welfare of sugar cane growers, needed assessment of the effectiveness of the program in achieving the goal of productivity of sugar cane, does its productivity increase? Does it give advantage for sugar cane farmers? Is some of these profits result set aside and rolled out again to be a source of funding for the strengthening of the venture capital group of farmers? These questions will be the focus of the study in this research.

Indicators of the success of PMUK is sugar cane farmers group is able to manage the appropriate capitalization norms of business through PMUK fund utilization, the increased productivity of farming PMUK receiver group, fertilizing and occurrence of capital so that the benefits of PMUK can reach wider target group. The results of the evaluations that have been conducted earlier found there were problems, including Strengthening venture capital Group (PMUK) were not rolling according to plan, and just scrolling more or less $32.3 \%$ of the total Fund existing PMUK caused farmers cannot obtain favorable results, in addition there is a idle PMUK funds (deposit) in the account of the sugar cane Growers Cooperative (KPTR) or personal account, so no impact to the strengthening of the venture capital group of farmers to get the productivity of sugar cane is expected.

Therefore it is interesting to do research to study the problems scientifically and more comprehensive about the effect of policy evaluation sugar cane development towards strengthening the performance of venture capital groups. The purpose of this research is to know the magnitude of the influence of evaluation policy the development of sugar cane people on performance strengthening venture capital groups.

\section{METHOD}

This study used a survey research method i.e. research that took a sample of a population and used the questionnaire as a tool to measure the data subject matter. This survey research studies used causal in cross sectional, to know the influence of a variable against other variables (exogenous variables influence against endogenous variables), with the design of the research as in table 1.

Table 1. Design Research

\begin{tabular}{|c|c|c|}
\hline No & The identity & Description \\
\hline 1. & Research Issues & $\begin{array}{l}\text { How big an influence Evaluation Policies on performance Strengthening } \\
\text { venture capital Group }\end{array}$ \\
\hline 2. & Research variables & $\begin{array}{l}\text { Exogenous variables: Policy Evaluation } \\
\text { Endogenous Variables: Strengthening Venture Capital Performance } \\
\text { Group }\end{array}$ \\
\hline 3. & $\begin{array}{l}\text { Measurement of } \\
\text { variables and data } \\
\text { collection } \\
\text { Techniques }\end{array}$ & $\begin{array}{l}\text { 1. A questionnaire with a scale rating (rating Scale) with a choice of } 5 \\
\text { answers, score the assessment scale } 1-5 \text { answer: very } \operatorname{good}(\mathrm{SB})=5 ;(\mathrm{B}) \\
=4 \text {; Good enough }(\mathrm{CB})=3 \text {; Not } \operatorname{good}(\mathrm{TB})=2 ; \operatorname{Bad}(\mathrm{BR})=1 \\
\text { 2. The structured interview. }\end{array}$ \\
\hline 4. & Sample Research & $\begin{array}{l}\text { Evaluators from the Directorate of Central Directorate General of } \\
\text { plantations of Annuals, Evaluators from the General Inspectorate } \\
\text { Inspectorate III Ministry of agriculture, the Evaluators of the province } \\
\text { consists of the production Bureau, Office of West Java Province, } \\
\text { Plantation Hall development of the seed Crop plantations, and the porch } \\
\text { of Certification and quality control of seeds, from The Office of District } \\
\text { Evaluators deal with Field Plantations in Majalengka Regency and } \\
\text { Cirebon district, with the following characteristics: } \\
\text { a. Evaluator Office of the county consists of the officer who handled } \\
\text { the production of sugar cane plant who has served for a minimum of } \\
3 \text { years } \\
\text { b. Evaluators from the Companion who directly serve the farmers of } \\
\text { sugar cane and has served for a minimum of } 3 \text { years. }\end{array}$ \\
\hline 5. & $\begin{array}{l}\text { The Sampling } \\
\text { Technique }\end{array}$ & Sampling areas with Proportional Allocation \\
\hline 6. & $\begin{array}{l}\text { Data Processing } \\
\text { Techniques }\end{array}$ & $\begin{array}{l}\text { The test gauge } \\
\text { The validity of using the corrected item-total correlation (person }\end{array}$ \\
\hline
\end{tabular}




\begin{tabular}{|l|l|}
\hline & correlation) \\
& Reliability with Cronbach Alpha \\
The Data processing Phase \\
To test the hypothesis were conducted Structural Equation Modeling \\
(SEM) processing of data through SPSS software and LISREL.
\end{tabular}

\section{Model Research}

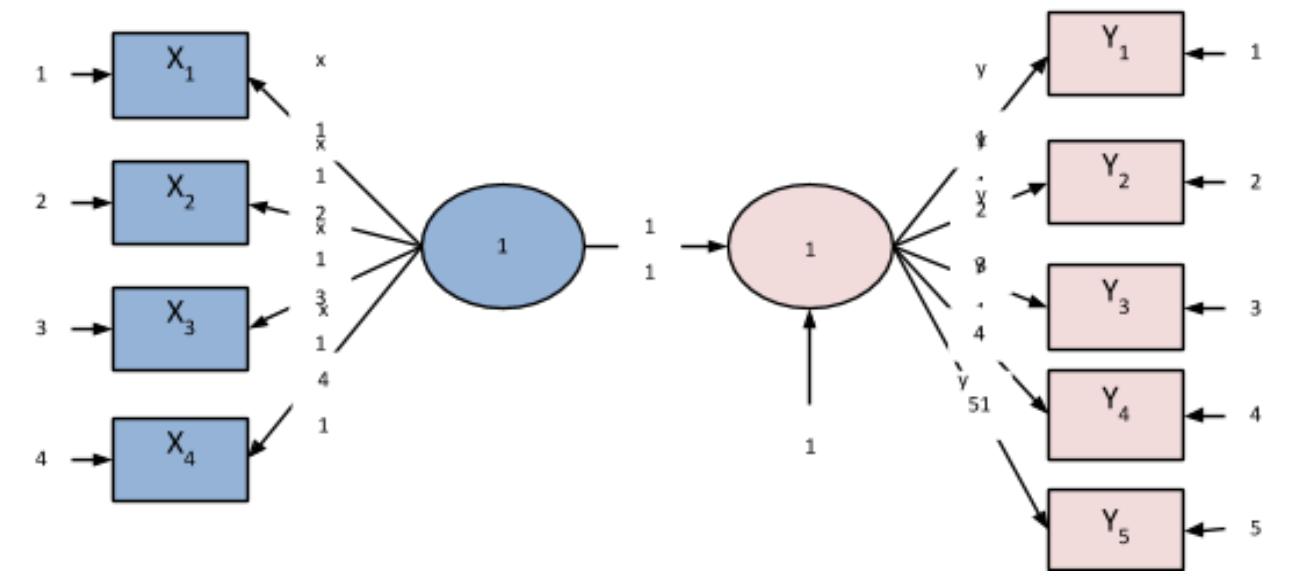

Figure 3.1. Model Research

\begin{tabular}{|l|l|l|}
\hline Description: & & \\
\hline Exogenous Variable $(\square)$ & $=$ & Evaluation Policy \\
\hline \multicolumn{1}{|c|}{$\eta \eta$} & $=$ & PMUK Performance \\
Endogenous Variable ( $)$ & & \\
\hline & $=$ & Causal Relationships \\
\hline
\end{tabular}

The variable Epsilon $(\square)=$ a factor that was not examined, among others, coordination, leadership, human resource management, incentive systems and others.

\section{OPERATIONAL RESEARCH VARIABLES}

Table 2. Operational Research Variables

\begin{tabular}{|c|c|c|}
\hline Variable & Dimension & Indicator \\
\hline \multirow{4}{*}{$\begin{array}{l}\text { Evaluation Policy } \\
\xi \\
\text { ( ) } \\
\text { (Bardach in Patton } \\
\text { Sawicki, 1986:156-157) }\end{array}$} & 1. Technical feasibility & $\begin{array}{l}\text { 1. Achievement of targets } \\
\text { 2. Problem solving efforts }\end{array}$ \\
\hline & $\begin{array}{l}\text { 2. Economic and financial } \\
\text { feasibility }\end{array}$ & $\begin{array}{l}\text { 1. the implementation of policies } \\
2 \text {. The advantages of } \\
\text { implementing policy }\end{array}$ \\
\hline & 3. Political support Resources & $\begin{array}{l}\text { 1. acceptance/support } \\
\text { 2. The usefulness of the results } \\
\text { 3. Ketanggapan program policy } \\
\text { issues } \\
\text { 4. Guarantee the results of the } \\
\text { implementation of the } \\
\text { 5. Justice for the community }\end{array}$ \\
\hline & $\begin{array}{l}\text { 4. Administrative } \\
\text { resources }\end{array}$ & $\begin{array}{l}\text { 1. The Authority implementing } \\
\text { policies owned } \\
\text { 2. The commitment of local } \\
\text { governments }\end{array}$ \\
\hline
\end{tabular}




\begin{tabular}{|c|c|c|}
\hline & & $\begin{array}{l}\text { 3. The expertise of the staff } \\
\text { support } \\
\text { 4. The ability of the financial } \\
\text { institutions } \\
5 \text {. The means for implementing } \\
\text { the policy }\end{array}$ \\
\hline \multirow[t]{5}{*}{$\begin{array}{l}\text { PMUK Performance () } \\
\text { (Abdul Basyid, 2006:2-3) }\end{array}$} & 1. Increase in capital stock & $\begin{array}{l}\text { 1. Frequency of revolving } \\
\text { 2. The amount of venture capital } \\
\text { results guliran } \\
\text { 3. Capital stock is not scrolling } \\
\text { Potential venture capital }\end{array}$ \\
\hline & 2. Increased production & $\begin{array}{l}\text { 1. The Unit cost of production } \\
\text { 2. The availability of the means } \\
\text { of production }\end{array}$ \\
\hline & 3. Business Development & $\begin{array}{l}\text { 1. Consumption } \\
\text { 2. Production } \\
\text { 3. save loan } \\
\text { 4. The service } \\
\text { 5. All-round effort }\end{array}$ \\
\hline & 4. Independence of the Group & $\begin{array}{l}\text { 1. ability to access Banking } \\
\text { 2. Regardless of Government } \\
\text { assistance }\end{array}$ \\
\hline & $\begin{array}{l}\text { 5. The growth of the rural } \\
\text { Economy Institute Institute }\end{array}$ & $\begin{array}{l}\text { 1. BUMDES (village-owned } \\
\text { enterprises) } \\
\text { 2. Organization of rural financial } \\
\text { intermediaries } \\
\text { 3. The rural social intermediary } \\
\text { 4. Agents rural economic } \\
\text { development }\end{array}$ \\
\hline
\end{tabular}

\section{Data Processing Techniques}

Because the study causal aimed to determine the effect of policy evaluation of the performance PMUK so the data processing techniques performed by Structure Equation Modeling ( SEM ), which in its calculations using LISREL software Description of the data necessary to obtain a general overview of the answers of the respondents tendency towards research each item so that it can be used as a reference in discussing the results of the research.

\section{Hypothesis Testing}

Technique of data analysis directed to answer a research problem has been identified and test hypotheses posed. Then discussed in depth to describe phenomena over the cases examined in this study. Based on the identification of problems and the proposed hypothesis, then the data analysis techniques used in this research is the analysis of Structural Equation Modeling (SEM). The purpose of this analysis is to describe the relationships of variables with other variables, so with this analysis can be known the influence of exogenous variables on endogenous variables directly. The magnitude of the effect of exogenous variables to the endogenous variables declared by the coefficient lines .

\section{RESULTS AND DISCUSSION}

The Results Of The Evaluation Of The Development Policy Of The People's Cane.

The responses of the respondents who became a sample research on 4 dimensions of Policy Evaluation, the following variables are presented in Table 4 below.

Table 4. Recap Of The Responses Of The Respondents Regarding The Evaluation Policy

\begin{tabular}{|l|l|l|l|l|}
\hline No & Dimensions & $\begin{array}{l}\text { Score } \\
\text { Total }\end{array}$ & Percentage & Criteria \\
\hline 1 & Technical feasibility & 2.351 & $70,2 \%$ & Medium \\
\hline
\end{tabular}


The Influence Evaluation Of People's Sugar Cane Development

\begin{tabular}{|l|l|l|l|l|}
\hline 2 & $\begin{array}{l}\text { Economic and financial } \\
\text { feasibility }\end{array}$ & 1.419 & $42,4 \%$ & Execrable \\
\hline 3 & The power of political support & 4.895 & $58,4 \%$ & $\mathrm{Bad}$ \\
\hline 4 & Administrative support resources & 6.285 & $75,0 \%$ & Good \\
\hline The Amount Of Score & & 14.950 & & Medium \\
\hline Percentage Score & & $63,8 \%$ & & \\
\hline
\end{tabular}

Source: Results of Questionnaire Research 2015 (processed).

Table 4 above illustrates the recapitulation of the responses of the respondents regarding the evaluation of the policy. The highest scoring is present on the dimension of the power of administrative support with the percentage of $75.0 \%$ and the lowest is present on the dimension of the economic and financial feasibility with percentage of $42,4 \%$. And the average assessment of the Policy Evaluation of $63.8 \%$. Assessment criteria for the evaluation of policy variables included in the criteria of being because of all the dimensions on the variable evaluation policy also varies.The condition was indeed quite logical, economic feasibility and financial dimension occupied the lowest position because the unit cost for the implementation of the development of sugar cane people was quite high but assisted by the Government only 30 percent for the fulfillment of the main means of production such as seeds, fertilizers, the aid of tillage, the rest becomes the burden of farmers by relying on credit KKPE package of banking into a full load of farmers so it required prudence in prediction of profit and loss calculation to anticipate payment of debts to banks, in addition to thinking of rollover for reinforcement of the capital.

Revolving strengthening of capital and to repay credit debt to banks only rely on profits from the production of sugar cane cultivated so that farmers need technical guidance as well as the motivation of the Government to be willing and able to earn a maximum of sugar cane in order to foster venture capital that continues to accumulation to be the continuous production factors having an impact on other farmers who have not received the Government's facilitation and haven't gotten credit banking package.

The role of Government was crucial and required his presence in the midst of cane farmers people as facilitators or liaison between farmer groups with its partners (sugar mill) and the banking parties in getting venture capital implementation of the cultivation of sugar cane, it was very helpful to farmers. The role has been carried out through operational technical team and a companion in the field who accompany the technical or administrative activities of the farmers group in power, even the companion KPTR was placed in the Office area of the sugar factory at KPTR Cirebon district and Majalengka Regency.

Different case with the response of farmers against the dimensions of the feasibility of the Administration response is relatively high i.e. 75\% (good) compared to other dimensions. This condition was supported by operational facilities farmer groups and facilities provided by the Government, such as equipment cultivation of sugar cane: Tractor and equipment, water pumps, harvesting equipment, computers, trucks and facilities that have been owned by farmer groups such as the Office KPTR and supporting facilities that were already available, so that to carry out the administrative process group was considered adequate, but the condition was not a major component to increase the production of sugar cane, the main thing was the dimensions of economic and financial feasibility was currently the least because it involved factors of production such as seeds, fertilizer and labor wages that are currently difficult to obtain and expensive.

\section{STRENGTHENING VENTURE CAPITAL PERFORMANCE GROUP}

Strengthening Performance Venture Capital Performance Group was an achievement of the implementation of specific activities that were targeted in the activities that were the target achievement Strengthening Venture Capital scroll Sugar cane Farmers People who carry out the Sugar Cane Farmers Development Program in Cirebon and Majalengka Regency.

To know responder comments about the variables Strengthening Venture Capital Performance Group can be seen in the Summary of Responses Respondents Strengthening Venture Capital Performance Group in Table 5 .

Table 5. Summary of Respondents Regarding Strengthening Venture Capital Performance Group

\begin{tabular}{|l|l|l|l|l|}
\hline No. & Dimensions & $\begin{array}{l}\text { Score } \\
\text { Total }\end{array}$ & Percentage & Criteria \\
\hline 1 & The increase in working capital & 4.002 & $59,7 \%$ & Bad \\
\hline 2 & Increased production & 2.278 & $68,0 \%$ & Medium \\
\hline
\end{tabular}


The Influence Evaluation Of People's Sugar Cane Development

\begin{tabular}{|l|l|l|l|l|}
\hline 3 & Business development & 7.340 & $87,6 \%$ & Excellent \\
\hline 4 & Independence group & 2.050 & $61,2 \%$ & Medium \\
\hline 5 & $\begin{array}{l}\text { The growth of rural economic } \\
\text { institutions }\end{array}$ & 3.424 & $68,1 \%$ & Medium \\
\hline Total Score & & 19.094 & & Good \\
\hline $\begin{array}{l}\text { Score } \\
\text { Percentage }\end{array}$ & $71,2 \%$ & & \\
\hline
\end{tabular}

Source: Results of Questionnaire Research 2015 (processed).

From the table above shows that that the highest scoring present on the dimension of the development effort with percentage of $87.6 \%$ (excellent) and the lowest is present on the dimension of the capital raising effort with percentage of $59.7 \%$ (bad). And the average assessment on Strengthening Performance Venture Capital Group amounted to $71.2 \%$ (good). Variable Performance assessment criteria the strengthening of venture capital groups are included in the criteria of good because almost all of the dimensions of the variable performance Strengthening Venture Capital Group also vary, that needed to be made more intensive coaching by the agencies which has the function of fostering cooperatives Micro, Small, Medium Enterprises i.e. Department of Cooperatives micro, Small and Medium Enterprises (KUMKM) at the district level that has not been done by the agency.

The condition was quite reasonable for Dimension Increase Business Capital, Increased Production, Independence Group and Growth Institutions Rural Economy at the Development Area Sugar Cane Farmers in Cirebon and Majalengka Regency was derived from sugar cane cultivation people gains result in regions each of which the results were less profitable, so it can not contribute to PMUK. It also depends on the potential for the production of sugar cane development results based on the results of the evaluation was determined by the technical feasibility, economic and financial feasibility, political feasibility, and administrative feasibility.

RESULTS OF TESTING HYPOTHESES BY LISREL:

PERFORMANCE $=0.640 *$ EVALUATION, Errorvar. $=0.590, \mathrm{R}^{2}=0.410$

$\begin{array}{cc}(0.0515) & (0.0536) \\ 12.419 & 11.013\end{array}$

From the results above, it can be seen that the latent variables exogenous coefficient Evaluation policy $\left(\xi_{1}\right)$ against endogenous latent variable Performance Strengthening venture capital Group ( $\left.\eta_{1}\right)$ by 0.640 indicating a strong relationship between Policy Evaluation $\left(\xi_{1}\right)$ with Performance Strengthening Venture Capital Group $\left(\eta_{1}\right)$. The value $t$ calculate 12.419 is greater than the specified critical limits $\pm 1.96, \mathrm{H}_{0}$ is rejected, so that means there is the influence of the evaluation policy $\left(\xi_{1}\right)$ on performance Strengthening venture capital Group $\left(\eta_{1}\right)$.The influence of the evaluation policy $\left(\xi_{1}\right)$ on performance Strengthening venture capital Group $\left(\eta_{1}\right)$ is indicated by the value of the $R$ square $\left(R^{2}\right.$ the value of $R$ square 0.410 shows contributions / influence Evaluation of Policy Development of people's Cane $(\xi 1)$ on the Performance Strengthening Venture Capital Group ( $\eta 1$ ) in Cirebon and Majalengka amounted to $41.0 \%$, the remaining $59.0 \%$ influenced by other variables not studied such coordination, leadership style, human resource management, incentive systems and others

\section{CONCLUSIONS AND SUGGESTIONS}

Evaluation of the development policy of the people's cane is significantly influential on performance strengthening venture capital groups in the District of Majalengka and Cirebon. The influence of the evaluation policy $(\xi 1)$ on performance Strengthening venture capital Group $(\eta 1)$ is indicated by the value of the R square $\left(\mathrm{R}^{2}\right)$, the value of R square 0.410 shows contributions / influence Evaluation of Policy Development of people's Cane $(\xi 1)$ on the Performance Strengthening Venture Capital Group ( $\eta 1)$ in Cirebon and Majalengka amounted to $41.0 \%$, the remaining $59.0 \%$ influenced by other variables not studied such coordination, leadership style, human resource management, incentive systems and others. The magnitude of the influence is determined predominantly by the carrying capacity of the administrative dimension, whereas the lowest dimension is economic and financial feasibility.

\section{SUGGESTIONS}

In order to do further research about the empowerment of farmer groups to develop sugar cane independently by utilizing the facilitation of commercial credit packages with interest subsidy provided by the government such as the People's Business Credit (KUR) which is adapted to the needs of sugar cane farmers and guarantees (avalist) sugar factory. In addition, the study of policy evaluation with a qualitative approach in order to uncover more detailed information about the problems of the development of sugar cane associated with the 
strengthening of venture capital groups by intensifying the technical development of cultivation and empowerment of farmer group approach to social and economic so that in addition to gaining a high sugar cane productivity can also grow and the growing micro-economic institutions in the rural area surrounding the development of sugar cane

\section{THANKS}

Further thanks to Promoter Team and the entire Civitas Academic Postgraduate of Social and Political Sciences, University of Padjadjaran Bandung who have supported the writing of this article.

\section{REFERENCE}

[1] Bardach, Eugene. 2012. A Practical Guide for Policy Analysis The Eightfold Path To More Effective Problem Solving. Fourth Edition. SAGE Publication Ltd.

[2] Boyne, G.A., Meier, Toole. Jr and Walker, 2006. Public Service Performance, Perspective Measurement and Management, New York: Cambridge University.

[3] Creswell, W.J. 1994. Research Design: Qualitative and Quantitative Approaches. California: Sage Publications, Inc.

[4] Dunn, William N. 1981. Public Policy Analysis: An Introduction. Prentice-Hall, Inc, Englewood Cliffs.

[5] Gibson, James L, Ivancevich, John M. Donnnely Jr. James H. 1995. Organisasi dan Manajemen Perilaku Struktur Proses. Alih Bahasa Wahid, Djoerban, Jakarta : Airlangga.

[6] Hari, Setyo Wijanto. 2008. Structural Equation Modeling dengan Lisrel 8.8 Konsep \& Totorial. Yogyakarta: Graha Ilmu.

[7] Jones, Charles O. 1996. Pengantar Kebijakan Publik. Jakarta : Raja Grafindo Persada.

[8] Nagel, Stuart S, ed., 1990, Policy Theory And Policy Evaluation, New York: Greenwood Press.

[9] Nugroho, Riant. 2004. Kebijakan Publik Formulasi, Implementasi, dan Evaluasi, Jakarta : Elex Media Komputindo.

[10] Patton, Carl V \& Sawicki, David.S. 1986. Basic Methos of Policy of Analysis and Planning. New York : Prentice Hall - Englewood Cliffs.

[11] Prijana. 2005. Metode Sampling Terapan untuk Penelitian Sosial. Penyunting Usin S. Artyasa. Bandung : Humaniora.

[12] Rossi, Peter H., \& Howard E. Freeman, 1993, Evaluation: A Systematic Approach, Newbury Park: Sage Publications.

[13] Wibawa, Samodra. 1994. Evaluasi Kebijakan Publik. Jakarta : Rajawali Press.

[14] Winarno Budi. 2002. Teori dan Proses Kebijakan Publik. Jakarta : Media Pressindo.

[15] Wollmann, Hellmut, 2003, Evaluation in Public Sector Reform: Concept And Practice In International Perspective, Massachusetts: Edward Elgar.

\section{Regulations / Document}

Regulation of the Minister of agriculture number: 03/Pert/HK.060/2/2006 concerning guidelines for testing and distribution of Funds Strengthening venture capital Group To target group On Agricultural development activities fiscal year 2006 .

\section{Electronic Reference}

Abdul Basyid. 2006. "Pemberdayaan Masyarakat Pertanian Melalui Penguatan Modal Usaha Kelompok Petani" melaluihttps://www.google.co.id/search?q=penguatan+modal+usaha+kelompok\&ie=utf- $8 \&$ oe=utf8\&rls=org.mozilla:en-US:official\&client=firefox-a\&gws_rd=cr\&ei=Ea6kU9WzHMW0uAThzYLABA digilib.litbang.deptan.go.id/repository/index.php/repository/.../6183 [22/6/2014].

Fadila Maulidah. 2012 "Perkembangan Kemitraan Petani Tebu Dengan PG. Krebet Baru, Perilaku Ekonomi PetaniTebu"melaluihttp://jurnalonline.um.ac.id/data/artikel/artikelF3A425BFCF1169584A09708ECFFDF07C.pdf [29/2/2016]. Fatih Al Andy. 2010. "Pengaruh Implementasi Kebijakan Kemitraan Terhadap Kinerja Usaha Kecil (Studi pada Usaha Kecil di Palembang Binaan PT. Pusri (Persero) Palembang)" melalui https://cisral.unpad.ac.id/ index.php/2010/11/25/ [14/3/2016].

Mat D. Duerden dan Peter A. Witt. (t.th). "Keys to Effective Implementation Evaluations" melalui http://www.csulb.edu/ msaintg/ppa670/670steps.htm [12/1/2014].

Wikipedia Bahasa Indonesia. "Indek Prestasi” melalui https://id.wikipedia.org/wiki/Indeks_prestasi 